\title{
Occupational asthma due to maleic anhydride
}

\author{
H S Lee, Y T Wang, T H Cheong, K T Tan, B E Chee, K Narendran
}

Few reported cases of asthma due to maleic anhydride have been reported, ${ }^{12}$ although there have been several cases due to other acid anhydrides. Our case is unique in that the patient was exposed to both maleic anhydride (MA) and phthalic anhydride (PA). He had a negative challenge test to PA but reacted positively to MA showing the absence of cross reactivity between the two anhydrides in his case.

\section{Case report}

A 34 year old man joined a factory manufacturing urea formaldehyde glue, expandable polystyrene, and alkyd and polyester resins in April 1988. In January 1990 he was transferred to the alkyd polyester section.

His job as an assistant technician included supervision of a process using various chemicals. He developed a cough, rhinitis, breathlessness, and wheezing about one month after working in this section. The symptoms developed within minutes of exposure to dust during the loading of chemicals into a reactor. This usually took place during the morning shift. He developed the symptoms only when loading was carried out during his shift. His symptoms worsened and in March 1990 he was admitted to hospital for an acute asthmatic attack. In April 1990 he was transferred to another job in the same section-the filling and packing of the final product (alkyd or polyester resin). He had complete relief of symptoms. On 31 May 1990 he helped to clear the inlet of the reactor, which was blocked. He was exposed to some dust from the reactor and immediately developed an acute asthmatic attack.

He had no history of asthma but had a history of vasomotor rhinitis before joining the factory. There was no family history of atopy or asthma. He smoked 20 cigarettes a day and had been smoking for the past 15 years.

\section{Occupational exposure}

The production of polyester resin was carried out about three times a week. Four workers were con-

Department of Industrial Health, Ministry of Labour

H S Lee, K T Tan

Department of Medicine III, Tan Tock Seng Hospital Y T Wang, T H Cheong, B E Chee

Department of Medicine, Toa Payoh Hospital Pte Ltd, Singapore

K Narendran cerned with batching the powdered chemicals into the reactor. Liquid propylene glycol was pumped into the reactor first. Then about 120 bags $(25 \mathrm{~kg}$ each) of PA crystals were emptied into the reactor manually followed by about 90 bags ( $25 \mathrm{~kg}$ each) of MA crystals. This process was visibly dusty, even though a local exhaust ventilation was provided, and took about two hours. Smaller quantities of powdered mono-pentaerythiritol were also added. Dust concentrations of PA during the process were $1.36 \mathrm{mg} / \mathrm{m}^{3}$ for inspirable particulate mass (IPM) and $0.33 \mathrm{mg} / \mathrm{m}^{3}$ for respirable particulate mass (RPM). Dust concentrations of MA were $0.83 \mathrm{mg} / \mathrm{m}^{3}$ for IPM and $0.17 \mathrm{mg} / \mathrm{m}^{3}$ for RPM. Measurements were made near the breathing zone using a quartz crystal microbalance (QCM) cascade impactor (Model PC-2).

The production of alkyd resin was carried out daily. The batching process was similar but the proportion of MA used was much less. About 80 bags ( $25 \mathrm{~kg}$ each) of PA were used compared with only two bags ( $25 \mathrm{~kg}$ each) of MA.

The MA and PA crystals used for both preparations were $98 \%$ pure.

\section{Bronchial provocation testing}

Bronchial provocation testing was done on an inpatient basis. The patient had already been transferred from the loading process for about a month. On the first day no provocation was carried out and a baseline peak flow rate (PEFR) was obtained. Each time, the highest of three PEFR recordings was taken. On the second day provocation to PA was carried out. The patient poured PA crystals from one bowl to another for 11 minutes. The maximum concentrations of exposure to PA dust were 0.64 $\mathrm{mg} / \mathrm{m}^{3}$ for IPM and 0.04 for RPM. The diurnal variation $(\mathrm{DV})$ in the peak flow rate was $16 \%$ (fig 1 ).

He was readmitted two weeks later and provocation was carried out with lactose dust for 12 minutes (in a similar manner) on the first day of admission. The average concentration of lactose dust was $3 \cdot 71$ $\mathrm{mg} / \mathrm{m}^{3}$ for IPM. The DV was $12 \cdot 7 \%$. On the second day provocation was carried out with MA crystals using the same procedure for 14 minutes. The average concentrations of MA dust were $0.83 \mathrm{mg} / \mathrm{m}^{3}$ for IPM and $0.09 \mathrm{mg} / \mathrm{m}^{3}$ for RPM. After two minutes of exposure he developed cough, rhinitis, and lacrimation. After eight minutes rhonchi were detected in both lungs and his PEFR had fallen by $23.6 \%$ 


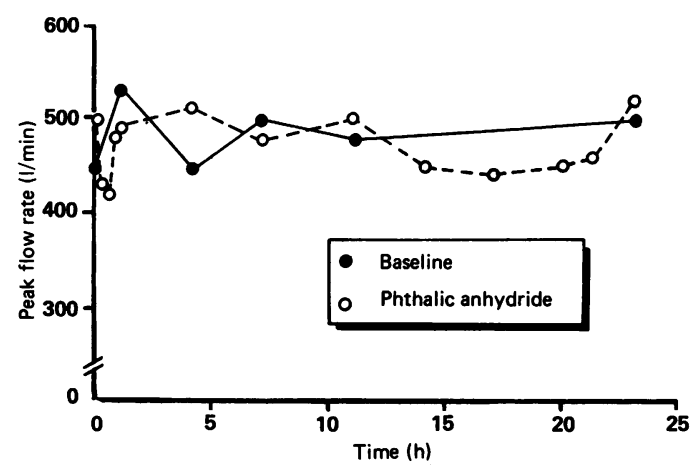

Figure 1 Peak expiratory flow baseline (day 1) and after exposure to phthalic anhydride (day 2 ).

from the baseline of $550 \mathrm{l} / \mathrm{min}$. The PEFR fell further to $360 \mathrm{l} / \mathrm{min}$ (fall of $35 \%$ ) after 15 minutes of exposure and then to $250 \mathrm{l} / \mathrm{min}$ (fall of $55 \%$ ), five minutes later. Nebulised ventolin was then given and his PEFR returned to $520 \mathrm{l} / \mathrm{min}$ ten minutes later with no more rhonchi heard. Eight hours later he again developed tightness of chest and his PEFR fell to $410 \mathrm{l} / \mathrm{min}(25.5 \%$ below the baseline). Nebulised ventolin was again given and his PEFR increased to $550 \mathrm{l} / \mathrm{min}$ and remained stable (fig 2).

Dust concentrations during the challenge tests were measured at one minute intervals with a QCM cascade impactor placed near the breathing zone of the patient.

\section{Other investigations}

The patient had non-specific bronchial hyperactivity as assessed by the provocative dose of histamine producing a $20 \%$ fall relative to a pretreatment forced expiratory volume in one second $\left(\mathrm{PD}_{20} /\right.$

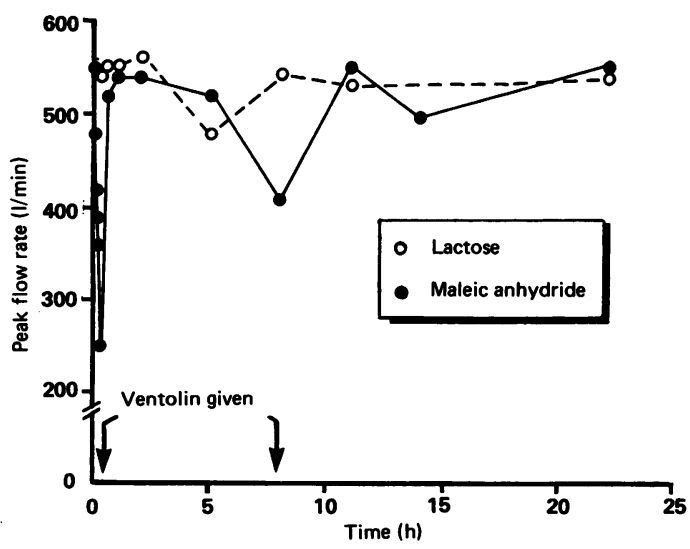

Figure 2 Peak expiratory flow after exposure to lactose (day 1) and after exposure to maleic anhydride (day 2).
$\mathrm{FEV}_{1}$ ). This was $0.26 \mu \mathrm{mol}$. Skin prick testing to common environmental allergens was positive for house dust, house dust mite, bermuda grass, common mugwort, and black willow. No immunological blood tests were carried out. Total white cell count was $10800 / \mathrm{dl}$ with $6 \%$ eosinophils. Chest $x$ ray film was normal.

\section{Discussion}

Our patient developed a dual asthmatic reaction to MA. Both cases of MA positive challenge tests reported by Durham et $a l^{2}$ also had a dual response. The concentration of MA dust to which he was exposed during the challenge test was well below the threshold limit value (TLV) of $1 \mathrm{mg} / \mathrm{m}^{3}$ recommended by the American Conference of Governmental Industrial Hygienists. ${ }^{3}$ Levels below the TLV should not be irritating to the non-sensitised person.

Maleic anhydride is more potent as an irritant to the skin and mucous membranes than PA. ${ }^{4}$ This is reflected in the appreciably higher TLV of $6 \mathrm{mg} / \mathrm{m}^{3}$ for PA. ${ }^{3}$ The other operators who had more direct exposure to MA than our patient, although complaining of irritative symptoms, did not have asthma.

There have been many more reports of PA asthma compared with MA asthma. ${ }^{5}$ The reason for this is not clear. It is interesting that our patient who had more exposure to PA than MA did not develop an asthmatic reaction to PA. There appears to be no cross reactivity between MA and PA in his case. Such cross reactivity has not been described but cross reactivity between tetrachlorophthalic anhydride (TCPA) and PA has been reported based on immunological tests. ${ }^{5}$

Our patient was atopic and a heavy smoker. Whether one or both of these factors have predisposed him to develop asthma is uncertain. So far no study of asthma caused by acid anhydrides has noted any strong association with atopy. ${ }^{5}$ Workers exposed to TCPA who were current smokers had a sixfold excess of anti TCPA IgE. ${ }^{6}$ Workers exposed to PA showed no difference in the prevalence of smoking between those with asthma and those without. ${ }^{7}$

Further studies on workers exposed to MA are needed to determine the prevalence of asthma and its association with atopy and smoking. It would also be interesting to study whether cross reactivity occurs between MA and other anhydrides.

1 Guerin JC, Deschamps O, Guillot TL, Chavaillon JM, Kalb JC. A propos d'un cas d'asthma a'l'anhydride maleigue. Poumon et la Coeur 1980;36:393-5.

2 Durham SR, Graneek BJ, Hawkins R, Newman Taylor AJ. The temporal relationship between increases in airway responsiveness to histamine and late asthmatic responses induced by occupational agents. J Allergy Clin Immunol 1987;79:398-406. 
3 American Conference of Governmental Industrial Hygienists. Threshold limit values for chemical substances and physical agents and biological exposure indices. Cincinnati: 1990-1991: 25.

4 American Conference of Governmental Industrial Hygienists. Documentation of the threshold limit values and the biological exposure indices. 4th ed. Cincinnati: 1981:250.

5 Venables KM. Low molecular weight chemicals, hypersensitivity, and direct toxicity: the acid anhydrides. $\mathrm{Br} J$ Ind $\mathrm{Med}$ 1989;46:222-32.
6 Venables KM, Topping MD, Howe $W$, Luceynska CM, Hawkins R, Newman Taylor AJ. Interaction of smoking and atopy in producing specific IgE antibody against a hapten protein conjugate. $B M J 1985 ; 290: 201-4$.

7 Wernfors M, Nielsen J, Shutz A, Skerfving S. Phthalic anhydride-induced occupational asthma. Int Arch Allergy Appl Immunol 1986;79:77-82.

Accepted 29 October 1990

From 1 July 1985 articles submitted for publication will not be returned. Authors whose papers are rejected will be advised of the decision and the manuscripts will be kept under security for three months to deal with any inquiries and then destroyed. 